\title{
Mechanism of Pb Removal from Brass Scrap by Compound Separation Using $\mathrm{Ca}$ and $\mathrm{NaF}$
}

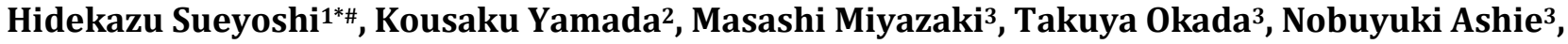 Yoshiharu Kousaka ${ }^{3}$}

${ }^{1}$ Graduate School of Science and Engineering, Kagoshima University, Kagoshima, Japan

${ }^{2}$ Kyushu Tabuchi Co. Ltd., Kirishima, Japan

${ }^{3}$ San-Etsu Metals Co. Ltd., Tonami, Japan

Email: *k9415634@kadai.jp, ko_yamada@kyushu-tabuchi.co.jp, kousaka@p2332.nsk.ne.jp

How to cite this paper: Sueyoshi, H., Yamada, K., Miyazaki, M., Okada, T. Ashie, N. and Kousaka, Y. (2018) Mechanism of $\mathrm{Pb}$ Removal from Brass Scrap by Compound Separation Using $\mathrm{Ca}$ and $\mathrm{NaF}$. International Journal of Nonferrous Metallurgy, 7, 1-7.

https://doi.org/10.4236/ijnm.2018.71001

Received: December 28, 2017

Accepted: January 25, 2018

Published: January 30, 2018

Copyright $\odot 2018$ by authors and Scientific Research Publishing Inc. This work is licensed under the Creative Commons Attribution International License (CC BY 4.0).

http://creativecommons.org/licenses/by/4.0/

\begin{abstract}
The Mechanism of $\mathrm{Pb}$ removal from brass scrap by compound separation using $\mathrm{Ca}$ and $\mathrm{NaF}$ addition was investigated. Because large $\mathrm{Ca}-\mathrm{Pb}$ compound particles formed by $\mathrm{Ca}$ addition rise to the surface of the molten brass, they can be skimmed off from the molten brass. However, fine $\mathrm{Ca}-\mathrm{Pb}$ compound particles remain in the molten brass because of low buoyancy. By subsequent $\mathrm{NaF}$ addition, the reaction between $\mathrm{Ca}-\mathrm{Pb}$ compound and $\mathrm{NaF}$ takes place at their contact regions, resulting in the formation of solid $\mathrm{CaF}_{2}$, liquid $\mathrm{Pb}$ and $\mathrm{Na}$ gas. $\mathrm{Pb}$ is mainly present at the $\mathrm{Ca}-\mathrm{Pb}$ compound- $\mathrm{CaF}_{2}$ interface. $\mathrm{CaF}_{2}$ acts as a binder for aggregation of fine $\mathrm{Ca}-\mathrm{Pb}$ compound particles, resulting in the formation of light and large composite compounds, which rise to the surface of the molten brass. A high $\mathrm{Pb}$ removal rate is achieved by skimming off.
\end{abstract}

\section{Keywords}

Lead Removal, Brass Scrap, Calcium, Sodium Fluoride, Compound Separation

\section{Introduction}

The machinability of brass alloys containing $\mathrm{Pb}$ is better than those of other metallic materials. However, $\mathrm{Pb}$ is a harmful substance that has neurotoxic effects and affects fertility. In Japan, the permitted level leached $\mathrm{Pb}$ in drinking water supplies was revised to $0.01 \mathrm{mg} / \mathrm{L}$ in April 2003 [1]. In European-based REACH program, the limit $\mathrm{Pb}$ content in brass alloys has been decreased $0.5 \mathrm{wt} \%$ from June 2016 [2]. In the USA, the $\mathrm{Pb}$ content in water-bearing materials has been limited to $0.25 \mathrm{wt} \%$ since 2014 [3].

\#ORCID of Hidekazu Sueyoshi is orcid.org/0000-0003-4422-3006. 
Brass alloys are mainly manufactured by recycling brass alloy scrap. The simplest strategy for $\mathrm{Pb}$ reduction is dilution using $\mathrm{Pb}$-free virgin materials. This method is used widely at present at most brass mills. However, the fundamental and troublesome problem is the accumulation of large amounts of unrecycled scrap. This confuses the recycling system functioning at present. The development of new technology for removing $\mathrm{Pb}$ from brass alloy scrap is urgent. For a hydrometallurgical approach, electrolytic decomposing in which main products were $\mathrm{Cu}$ and $\mathrm{Zn}$ cathodes plus $\mathrm{Pb}$-bearing anode sludge was patented in 2012 [4]. Besides hydrometallurgical decomposing, pyrometallurgical decomposing based on vacuum distillation and subsequent converting of remaining leaded brass is widely known and applicable to leaded brass [5]. However, large additional infrastructure is needed at most brass mills. Compound separation method is the most practical method because no additional infrastructure is needed [5]. A method for $\mathrm{Pb}$ removal by compound separation using $\mathrm{Ca}-\mathrm{Si}$ compound and $\mathrm{NaF}$ addition was first reported by the authors et al. [6] [7]. Hilgendorf et al. reported a fluorine-free method involving $\mathrm{Ca}$ addition alone [5]. However, there are few reports about $\mathrm{Pb}$ removal using compound separation.

According to the results reported as yet [5] [6] [7], the $\mathrm{Pb}$ removal rate was about $20 \%$ in the case of $\mathrm{Ca}-\mathrm{Si}$ compound or $\mathrm{Ca}$ addition alone and increased to $83 \%$ on subsequent $\mathrm{NaF}$ addition. However, the reasons for the effect of $\mathrm{NaF}$ on $\mathrm{Pb}$ removal have not been elucidated. Clarification of this removal mechanism would enable the development of methods for $\mathrm{Pb}$ removal by $\mathrm{Ca}$ and $\mathrm{NaF}$ additions and for fluorine-free $\mathrm{Pb}$ removal. This mechanism was therefore investigated in the present study.

\section{Experimental}

Brass scrap (chemical composition: 59.6 wt \% Cu, 3.2 wt \% Pb, 0.3 wt \% Sn, 0.16 wt $\% \mathrm{Fe}, 0.05 \mathrm{wt} \% \mathrm{Ni}$, bal. Zn, ingot weight: $10 \mathrm{~kg}$ ) was charged and then melted in a graphite crucible of $165 \mathrm{~mm}$ outer diameter, $139 \mathrm{~mm}$ inner diameter and $210 \mathrm{~mm}$ height (Nippon Crucible, Tokyo, Japan) in a high-frequency (6 - $9 \mathrm{kHz})$ induction furnace (MELT-COMP-80K, Tamagawa Engineering, Fukushima, Japan) in the atmosphere. The temperature was monitored with an inset type of optical fibre pyrometer (FIMTHERM-HM, Seiyo Industry, Yokohama, Japan). A Ca-cored brass wire of $13.6 \mathrm{~mm}$ outer diameter and $12.8 \mathrm{~mm}$ inner diameter (WING ON, Tokyo, Japan) was added to the molten brass at $1193 \mathrm{~K}$, followed by manual agitation for $1 \mathrm{~min}$ and holding for $5 \mathrm{~min}$. The addition amount of $\mathrm{Ca}$ was $2 \mathrm{wt} \%$. The temperature of the molten brass rose to $1223 \mathrm{~K}$ because of an exothermic reaction. After skimming off the floating slag using a ladle, a small sample disk of $40 \mathrm{~mm}$ diameter and $25 \mathrm{~mm}$ height for chemical analysis was produced by partial casting using the ladle and metal molds. NaF (Showa Chemical, Tokyo, Japan) of $4 \mathrm{wt} \%$ was then added to the molten brass at 1223 $\mathrm{K}$, followed by manual agitation for $1 \mathrm{~min}$ and holding for $5 \mathrm{~min}$. The slag and a small sample disk were similarly collected. The slag was characterized using 
scanning electron microscopy-energy dispersive X-ray spectroscopy (SEM-EDS) (SEM; JSM-7001F, JEOL, Tokyo, Japan, EDS; INCAx-act, Oxford Instruments, Oxfordshire, United Kingdom) and X-ray diffraction (XRD) (Smart Lab 9 kW, Rigaku, Tokyo, Japan) with $\mathrm{Cu}-\mathrm{Ka}$ radiation. The electric voltage and current applied to the X-ray tube used for XRD were $45 \mathrm{kV}$ and $200 \mathrm{~mA}$, respectively. The scanning rate and step angle were $50^{\circ} / \mathrm{min}$ and $0.02^{\circ}$, respectively. The chemical composition and microstructure of the small sample disk were examined using X-ray fluorescence (Simultix 14, Rigaku, Tokyo, Japan) and SEM-EDS, respectively.

\section{Results and Discussion}

The $\mathrm{Pb}$ removal rate after $\mathrm{Ca}$ addition was $15 \%$. Figure 1 shows the XRD pattern of the slag after $\mathrm{Ca}$ addition. Large amounts of $\mathrm{ZnO}$ [8] and small amounts of $\mathrm{CuO}$ [8], $\mathrm{CaO}$ [9] and $\mathrm{Ca}_{2} \mathrm{PbO}_{4}$ [10] were identified, but no $\mathrm{PbO}$ was identified. The standard Gibbs free energies $\left(\Delta G^{\circ}\right)$ of the oxidation of $\mathrm{Zn}, \mathrm{Cu}, \mathrm{Pb}$ and $\mathrm{Ca}$ at $1223 \mathrm{~K}$ were calculated using HSC Chemistry 5 software (Outokumpu Research). The values of $\Delta G^{\circ}$ for $\mathrm{ZnO}, \mathrm{CuO}, \mathrm{PbO}$ and $\mathrm{CaO}$ were $-447,-95,-198$ and $-1012 \mathrm{~kJ} / \mathrm{mol}$, respectively. The $\Delta G^{\circ}$ value of $\mathrm{ZnO}$ is lower than those of $\mathrm{CuO}$ and $\mathrm{PbO}$. This suggests that $\mathrm{ZnO}$ is formed in preference to $\mathrm{CuO}$ and $\mathrm{PbO}$ in the molten brass. The presence of large amounts of $\mathrm{ZnO}$ in the slag is caused by this phenomenon. However, small amounts of $\mathrm{CuO}$ also exist in the slag as shown in Figure 1. This is caused by atmospheric oxidation of brass alloy contaminated in the slag during skimming off, which is achieved during air cooling after skimming off. The reaction between $\mathrm{Ca}$ and $\mathrm{Pb}$ occurs by $\mathrm{Ca}$ injection into the molten brass, resulting in the formation of a $\mathrm{Ca}-\mathrm{Pb}$ compound. The oxidation of $\mathrm{Ca}$ also occurs because the $\Delta G^{\circ}$ value of $\mathrm{CaO}$ is lower than that of $\mathrm{ZnO}$. The presence of small amounts of $\mathrm{CaO}$ in the slag is caused by this phenomenon.

Figure 2 shows the SEM-EDS results for the small sample disk after Ca addition. $\mathrm{Ca}$ and $\mathrm{Pb}$ can be detected in the white region in the SE image. This indicates the presence of the $\mathrm{Ca}-\mathrm{Pb}$ compound in the molten brass. It is known that $\mathrm{Ca}_{2} \mathrm{~Pb}$ is formed at $\mathrm{Ca}$ addition of $2 \mathrm{wt} \%$ [5]. The $\Delta G^{\circ}$ value for the reaction

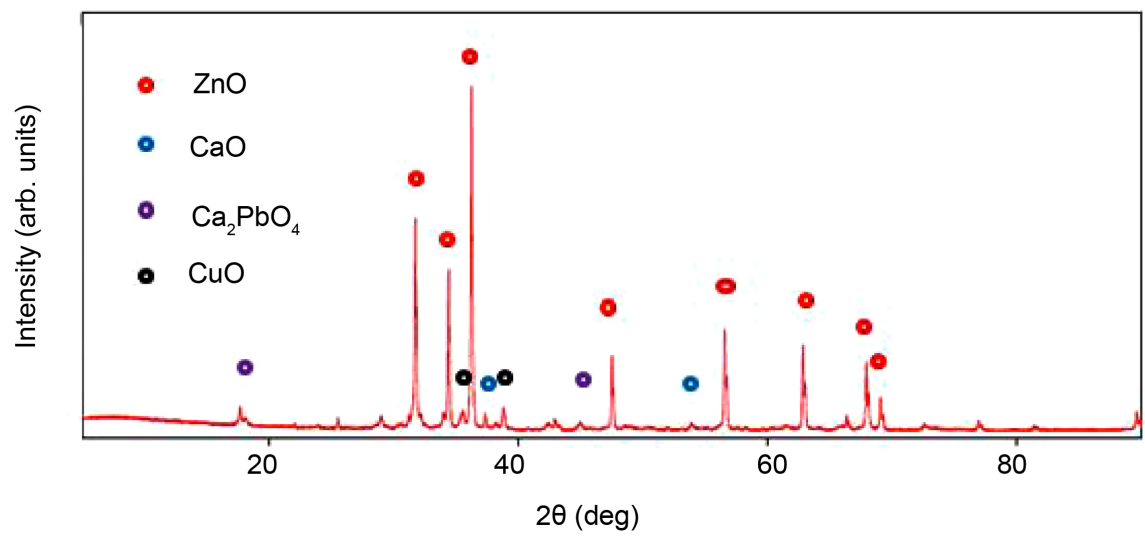

Figure 1. XRD pattern of slag after $\mathrm{Ca}$ addition. 


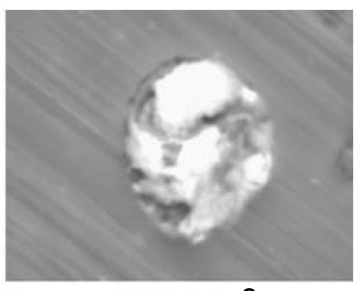

SE

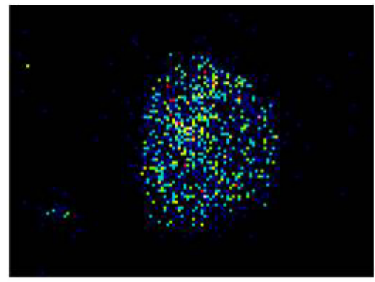

$\mathrm{Ca}$

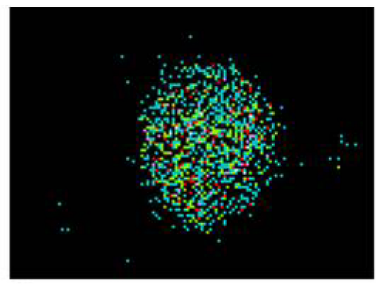

$\mathrm{Pb}$

Figure 2. SEM-EDS results for small sample disk after Ca addition.

between the $\mathrm{O}_{2}$ gas in air and $\mathrm{Ca}_{2} \mathrm{~Pb}$ (Equation (1)) was calculated using HSC Chemistry 5 software.

$$
\frac{1}{2} \mathrm{Ca}_{2} \mathrm{~Pb}+\mathrm{O}_{2}=\frac{1}{2} \mathrm{Ca}_{2} \mathrm{PbO}_{4}
$$

The value of $\Delta G^{\circ}$ at $1223 \mathrm{~K}$ was $-425 \mathrm{~kJ} / \mathrm{mol}$. This value is negative, therefore the reaction can occur. The results show that $\mathrm{Ca}_{2} \mathrm{~Pb}$ is formed in the molten brass after $\mathrm{Ca}$ addition and then $\mathrm{Ca}_{2} \mathrm{PbO}_{4}$ is formed by atmospheric oxidation of $\mathrm{Ca}_{2} \mathrm{~Pb}$ during air cooling after skimming off. The large $\mathrm{Ca}_{2} \mathrm{~Pb}$ particles that rise to the surface of the molten brass can be skimmed off, but fine $\mathrm{Ca}_{2} \mathrm{~Pb}$ particles remain in the molten brass. $\mathrm{A}$ high $\mathrm{Pb}$ removal rate therefore cannot be achieved by $\mathrm{Ca}$ addition alone.

The $\mathrm{Pb}$ removal rate after $\mathrm{NaF}$ addition was $72 \%$. The SEM-EDS results for the slag after $\mathrm{NaF}$ addition are shown in Figure 3. Regions in which $\mathrm{Ca}, \mathrm{Pb}$ and $\mathrm{O}$ coexist $\left(\mathrm{Ca}_{2} \mathrm{PbO}_{4}\right)$ and $\mathrm{Pb}$ and $\mathrm{O}$ coexist $(\mathrm{PbO})$ are present. $\mathrm{Ca}, \mathrm{Na}, \mathrm{Zn}, \mathrm{F}$ and $\mathrm{O}$ are all present in the same region. This suggests that $\mathrm{Ca}$ and $\mathrm{Na}$ fluorides and $\mathrm{Ca}$ and $\mathrm{Zn}$ oxides coexist.

Figure 4 shows the XRD pattern of the slag after $\mathrm{NaF}$ addition. NaF [11], $\mathrm{ZnO}, \mathrm{CaO}, \mathrm{Ca}_{2} \mathrm{PbO}_{4}, \mathrm{CaF}_{2}$ [12], and $\mathrm{PbO}$ [13] were identified. However, no $\mathrm{CuO}$ was identified. This may be caused by few brass alloy contamination in the slag. $\mathrm{PbO}$, as well as $\mathrm{Ca}_{2} \mathrm{PbO}_{4}$, is thought to be formed by atmospheric oxidation of $\mathrm{Pb}$ during air cooling after skimming off. This suggests that $\mathrm{Pb}$ is present in the molten brass. The presence of $\mathrm{Pb}$ is caused by the decomposition of $\mathrm{Ca}_{2} \mathrm{~Pb}$. Similarly, the presence of $\mathrm{Ca}_{2} \mathrm{PbO}_{4}$ in the slag indicates that $\mathrm{Ca}_{2} \mathrm{~Pb}$ is present in the molten brass. It is considered that most of the $\mathrm{Ca}_{2} \mathrm{~Pb}$ does not decompose in the molten brass and remains unchanged. This suggests that the $\mathrm{Ca}_{2} \mathrm{~Pb}-\mathrm{NaF}$ reaction occurs mainly at their contact region.

The $\Delta G^{\circ}$ values for the reaction between $\mathrm{NaF}$ and $\mathrm{Ca}_{2} \mathrm{~Pb}$ (Equation (2)) and $\mathrm{NaF}$ and excess $\mathrm{Ca}$ not involved in the $\mathrm{Ca}-\mathrm{Pb}$ reaction (Equation (3)) were calculated using HSC Chemistry 5 software.

$$
\begin{gathered}
\frac{1}{4} \mathrm{Ca}_{2} \mathrm{~Pb}+\mathrm{NaF}=\frac{1}{2} \mathrm{CaF}_{2}+\frac{1}{4} \mathrm{~Pb}+\mathrm{Na} \\
\frac{1}{2} \mathrm{Ca}+\mathrm{NaF}=\frac{1}{2} \mathrm{CaF}_{2}+\mathrm{Na}
\end{gathered}
$$

The values of $\Delta G^{\circ}$ for reactions (2) and (3) at $1223 \mathrm{~K}$ were -26.8 and -62.4 

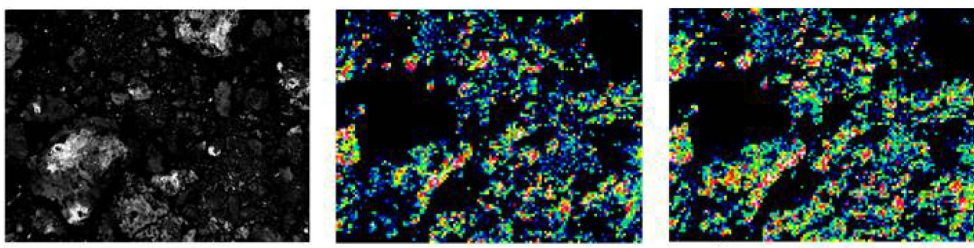

$$
\text { SE }
$$

$\mathrm{F}$

$\mathrm{Na}$
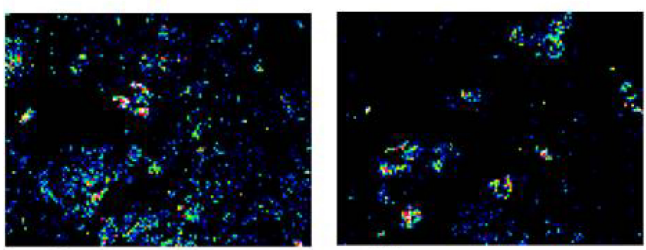

$\mathrm{Pb}$

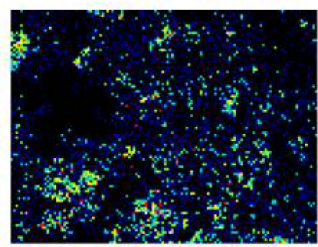

$\mathrm{Zn}$

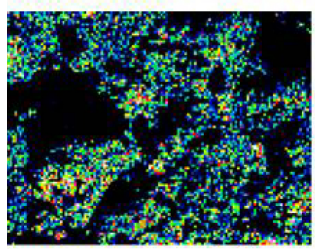

$\mathrm{O}$

Figure 3. SEM-EDS results for slag after $\mathrm{NaF}$ addition.

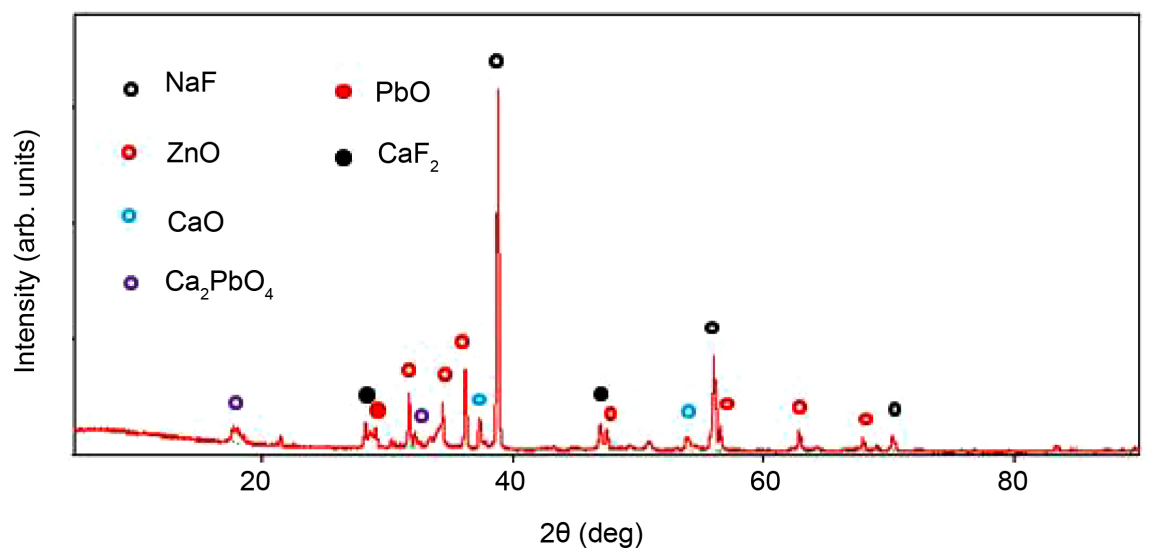

Figure 4. XRD pattern of slag after $\mathrm{NaF}$ addition.

$\mathrm{kJ} / \mathrm{mol}$, respectively. Because both values are negative, these reactions can occur. The value for reaction (3) is lower than that for reaction (2). Therefore, reaction (3) occurs preferentially until the excess $\mathrm{Ca}$ is almost all consumed, and then reaction (2) occurs.

In the molten brass at $1223 \mathrm{~K}, \mathrm{Ca}_{2} \mathrm{~Pb}$ and $\mathrm{CaF}_{2}$ are solid because the melting points of $\mathrm{Ca}_{2} \mathrm{~Pb}$ and $\mathrm{CaF}_{2}$ are 1469 and $1691 \mathrm{~K}$, respectively [14]. The melting point of $\mathrm{NaF}$ is $1266 \mathrm{~K}$. Therefore, $\mathrm{NaF}$ is present in solid form. $\mathrm{Pb}$ which has a low melting point $(600 \mathrm{~K})$ is present as a liquid. Na becomes a gas because of its low vaporization temperature (1156 K).

A schematic illustration of the mechanism of $\mathrm{Pb}$ removal based on the above results is shown in Figure 5. On $\mathrm{NaF}$ addition, the reaction (2) occurs at the $\mathrm{Ca}_{2} \mathrm{~Pb}-\mathrm{NaF}$ contact region, resulting in the formation of $\mathrm{CaF}_{2}$ (solid), $\mathrm{Pb}$ (liquid), 


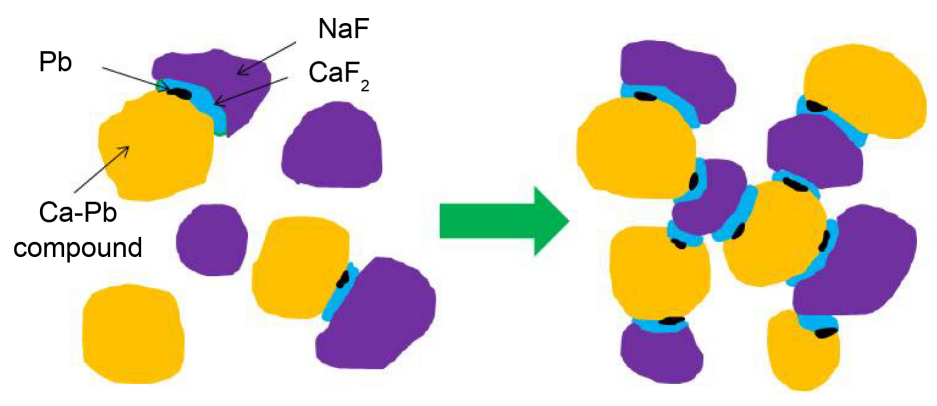

Figure 5. Schematic illustration of mechanism of $\mathrm{Pb}$ removal using $\mathrm{Ca}$ and $\mathrm{NaF}$ addition.

and $\mathrm{Na}$ (gas). It is considered that $\mathrm{Pb}$ is mainly present at the $\mathrm{Ca}_{2} \mathrm{~Pb}_{-} \mathrm{CaF}_{2}$ interface. $\mathrm{Na}$ gas is released from the molten brass. By agitating after NaF addition, multiple aggregation of residual fine $\mathrm{Ca}_{2} \mathrm{~Pb}$ particles is promoted by $\mathrm{Ca}_{2} \mathrm{~Pb}-\mathrm{CaF}_{2}-\mathrm{NaF}$ joining, resulting in the formation of large composite compounds. Thus, $\mathrm{CaF}_{2}$ acts as a binder for aggregation of fine $\mathrm{Ca}_{2} \mathrm{~Pb}$ particles. The densities of these large composite compounds are low because the densities of $\mathrm{NaF}\left(2.79 \mathrm{~g} / \mathrm{cm}^{3}\right)$ and $\mathrm{CaF}_{2}\left(3.18 \mathrm{~g} / \mathrm{cm}^{3}\right)$ are lower than that of $\mathrm{Ca}_{2} \mathrm{~Pb}\left(4.8 \mathrm{~g} / \mathrm{cm}^{3}\right)$ [14]. These light and large composite compounds rise to the surface of the molten brass because of high buoyancy. $\mathrm{A}$ high $\mathrm{Pb}$ removal rate is achieved by skimming off.

In the case of $\mathrm{Pb}$ removal by $\mathrm{Ca}$ addition alone, excess $\mathrm{Ca}$ causes new and complicated problems such as precipitation of $\mathrm{Ca}-\mathrm{Zn}$ intermetallic compounds during solidification [5]. However, this problem can be solved because the excess $\mathrm{Ca}$ is nearly all consumed by $\mathrm{NaF}$ addition (reaction (3)).

\section{Conclusion}

In the case of $\mathrm{Ca}$ addition alone, fine $\mathrm{Ca}_{2} \mathrm{~Pb}$ particles remain in the molten brass because of low buoyancy. Subsequent $\mathrm{NaF}$ addition leads to $\mathrm{CaF}_{2}$ formation by a reaction occurring at the $\mathrm{Ca}_{2} \mathrm{~Pb}-\mathrm{NaF}$ contact region. Large composite compounds are formed by multiple aggregation of residual fine $\mathrm{Ca}_{2} \mathrm{~Pb}$ particles because $\mathrm{CaF}_{2}$ acts as a binder between $\mathrm{Ca}_{2} \mathrm{~Pb}$ and $\mathrm{NaF}$. These light and large composite compounds rise easily to the surface of the molten brass, enabling $\mathrm{Pb}$ separation by skimming off. A high $\mathrm{Pb}$ removal rate is therefore achieved. Thus, the key issues of a successful process are thermodynamics and kinetics of compound particles. In particular, the relationship between additive and buoyancy needs further investigations.

\section{Acknowledgements}

This work was supported by the Ministry of Economy, Trade and Industry of Japan under Grant [Energy saving recycling process support project].

\section{References}

[1] Japan Foundry Engineering Society (2002) Chuzo-KogakuBinran (In Japanese). 
Maruzen, Tokyo, 473-474.

[2] European Commission (2015) Commission Regulation (EU) 2015/628 Amending Annex XVII to Regulation (EU) No 1907/2006 of the European Parliament and of the Council on the Reaction, Evaluation, Authorization and Restriction of Chemicals ("REACH") as Regard Lead Its Compounds. European Commission, Brussels.

[3] The Safe Drinking Water Act (2011) An Act to Amend the Safe Drinking Water Act to Reduce Lead in Drinking Water of 20002, Publ. L. No 111-380, Sec. 2 (d) (1) (B), Washington.

[4] Grohbauer, A. and Wieland-Werke, A.G. (2012) Verfahrenzur Abtrennung von Bleiausdem Messing-Recycling-Kreislauf. DE102011012133A1. German Patent and Trade Mark Office, Munich.

[5] Hilgendorf, S., Binz, F., Welter, J.M. and Friedrich, B. (2016) Lead Removal from Brass Scrap by Fluorine-Free Compound Separation. Materials Science and Technology, 32, 1782-1788. https://doi.org/10.1080/02670836.2016.1223574

[6] Yamada, K., Rochman, N.T., Fujimoto, R., Suehiro, S. and Sueyoshi, H. (2001) Removal of Lead from Scrap Brass. Journal of Advanced Science, 13, 273-276.

https://doi.org/10.2978/jsas.13.273

[7] Nakano, A., Rochman, N.T. and Sueyoshi, H. (2005) Removal of Lead from Copper Alloy Scrap by Compound-Separation Method. Materials Transactions, 46, 2719-2724. https://doi.org/10.2320/matertrans.46.2719

[8] Garcia Martinez, O., Rojas, R.M., Vila, E. and Martin De Vidales, J.L. (1993) Microstructural Characterization of Nanocrystals of $\mathrm{ZnO}$ and $\mathrm{CuO}$ Obtained from Basic Salts. Solid State Ionics, 63/65, 442-449. https://doi.org/10.1016/0167-2738(93)90142-P

[9] McMurdie, H.F., Morris, M.C., Evans, E.H., Paretzkin, B., Wong, W., Ettlinger, L. D. and Hubbard, C.R. (1986) Standard X-Ray Diffraction Powder Patterns from the JCPDS Research Associateship. Powder Diffraction, 1, 265-275. https://doi.org/10.1017/S0885715600011829

[10] Shiloh, M., Wood, I., Brown, M., Beech, F. and Boyd, I.W. (1990) Formation of $(\mathrm{Ca} 1-\mathrm{XSrx})_{2} \mathrm{PbO}_{4}$ in $\mathrm{Bi}(\mathrm{Pb})-\mathrm{Sr}-\mathrm{Ca}-\mathrm{Cu}-\mathrm{O}$ System :Correlation with the Formation of the 2223 High-Tc Phase. Journal of Applied Physics, 68, 2304-2307. https://doi.org/10.1063/1.346535

[11] McMurdie, H.F., Morris, M.C., Evans, E.H., Paretzkin, B., Wong, W., Ettlinger, L.D. and Hubbard, C.R. (1986) Standard X-Ray Diffraction Powder Patterns from the JCPDS Research Associateship. Powder Diffraction, 1, 64-77. https://doi.org/10.1017/S0885715600011593

[12] Gerward, L., Olsen, J. S., Steenstrup, S., Malinowski, M., Asbrink, S. and Waskowska, A. (1992) X-Ray Diffraction Investigations of $\mathrm{CaF}_{2}$ at High Pressure. Journal of Applied Crystallography, 25, 578-581. https://doi.org/10.1107/S0021889892004096

[13] McMurdie, H.F., Morris, M.C., Evans, E.H., Paretzkin, B., Wong, W., Zhang, Y. and Hubbard, C.R. (1987) Standard X-Ray Diffraction Powder Patterns from the JCPDS Research Associateship. Powder Diffraction, 2, 41-52.

https://doi.org/10.1017/S0885715600012239

[14] Yang, Z., Shi, D., Wen, B., Melnik, R., Yao, S. and Li, T. (2010) First-Principle Studies of $\mathrm{Ca}-\mathrm{X}(\mathrm{X}=\mathrm{Si}, \mathrm{Ge}, \mathrm{Sn}, \mathrm{Pb})$ Intermetallic Compounds. Journal of Solid State Chemistry, 183, 136-143. https://doi.org/10.1016/j.jssc.2009.11.007 